\title{
MACROECONOMIC REGIMES, POLICIES, AND OUTCOMES IN THE WORLD***
}

\author{
REGIIMENES, POLÍTICAS Y RESULTADOS MACROECONÓMICOS EN \\ EL MUNDO
}

\author{
Klaus SCHMIDT-HebBEL ***
}

\begin{abstract}
This paper summarizes a research project focused on the empirical determinants of and interrelations between macroeconomic regimes, policies, and performance in the world. The project's hypotheses are structured into three related themes. The first aim is analyzing the determinants of the likelihood of adoption of macroeconomic policy regimes. The second project theme focuses on cyclicality of macroeconomic policies and accuracy in attaining inflation targets. Finally, the project tests for the behavior of two key macroeconomic variables-economic growth and inflation-focusing on their sensitivity to different macroeconomic regimes and policies. A large world database was assembled for this project from both publicly available and private databases. Data coverage extends to more than 100 countries, with annual time series extending from 1970 to 2008. A wide spectrum of frontier estimation techniques is applied to the country panel data series, appropriate for discrete-choice and continuous variable estimation. The key research results are the following. Country choice of macroeconomic policy regimes (exchange-rate regimes, money-based targeting, inflation targeting, and rule-based fiscal regimes) is explained by countries' structural and institutional features, macroeconomic performance, financial development, and international integration. The cyclical behavior of fiscal policy reflects the quality of country institutions, financial openness, and financial development. Central bank accuracy in meeting inflation targets is also a result of domestic institutional strength and macroeconomic credibility. Long-term growth is significantly shaped by the quality of policies, financial development, foreign aid, and exchange-rate misalignment, in addition to standard growth determinants. Growth volatility is a
\end{abstract}

* This paper is based on my Presidential Address delivered at the September 2008 Annual Meetings of the Chilean Economic Society (Sociedad de Economía de Chile) in Viña del Mar. I gratefully acknowledge financial support provided by Fondecyt research project $\mathrm{N}^{\circ} 1060175$.

** I dedicate this paper to the memory of my beloved son Diego Schmidt-Hebbel, with whom I discussed the progress of this research agenda - the last time, when we were driving to the 2008 Viña del Mar Meetings.

*** Catholic University of Chile. email: kschmidt-hebbel@uc.cl 
result of domestic macroeconomic policy volatility, external shocks, international integration, and financial development. Country inflation rates are determined by international factors and domestic determinants, including fiscal policy, institutional development, monetary and exchange-rate regimes, and financial depth and integration.

Key words: Macroeconomic regimes, Macroeconomic policies, Inflation, Growth.

\section{Resumen}

Este trabajo sintetiza los resultados de un proyecto de investigación centrado en las relaciones entre y los determinantes empíricos de regímenes, políticas y resultados macroeconómicos en el mundo. Las hipótesis del proyecto están estructuradas en tres temas relacionados. El primero es el análisis de los determinantes de la probabilidad de adopción de distintos regímenes macroeconómicos. El segundo tema se centra en el carácter cíclico de las políticas macroeconómicas y la precisión en alcanzar las metas de inflación. Finalmente, el proyecto analiza el comportamiento de dos variables macroeconómicas claves -el crecimiento económico y la inflación-identificando su respuesta a distintos regímenes y políticas macroeconómicas. Una gran base de datos mundiales fue reunida para este proyecto, a partir de fuentes de datos de acceso público y privado. La cobertura de datos se extiende a más de 100 países, con observaciones anuales desde 1970 y hasta 2008. Un amplio espectro de técnicas de estimación de frontera es aplicada a los paneles de datos de países, tanto para la estimación de datos de selección discreta como para datos continuos. Los principales resultados empíricos son los siguientes. La selección de regímenes macroeconómicos (sistemas cambiarios, metas monetarias, metas de inflación y regímenes fiscales basados en reglas) está determinada por condiciones estructurales e institucionales de los países respectivos, así como por su desempeño macroeconómico, apertura financiera y desarrollo financiero. La precisión de los bancos centrales para alcanzar sus metas de inflación está influida por la fortaleza institucional y la credibilidad macroeconómica de los respectivos países. El crecimiento de largo plazo está determinado por la calidad de las políticas, el desarrollo financiero, la ayuda externa y la desalineación cambiaria, así como por otros determinantes estándares del crecimiento. La volatilidad del crecimiento es un resultado de la volatilidad de las políticas macroeconómicas domésticas, los shocks externos, la integración internacional y el desarrollo financiero. Las tasas de inflación de los países están determinadas por factores internacionales y domésticos, incluyendo la política fiscal, el desarrollo institucional, los regímenes cambiarios y monetarios, la profundidad financiera y la integración financiera.

Palabras clave: Regímenes macroeconómicos, Políticas macroeconómicas, Inflación, Crecimiento.

JEL Classification: E58, E62, O47. 


\section{INTRODUCTION}

Macroeconomic regimes and policies evolve over time. Fifty years ago the conduct of monetary, fiscal, and exchange-rate policies was opaque, discretionary, and unpredictable, not bound by well-defined policy regimes, institutions, and rules. Slowly since the 1980s, and more quickly since the 1990s and 2000s, macroeconomic policy regimes have been strengthened by the adoption of macroeconomic institutions (like independent central banks and fiscal councils), new policy regimes (like inflation targeting and fiscal rules), and more transparent policy decisions that are bound by ex-ante rules and ex-post accountability (like monetary policy decisions by modern central banks). This has been the result of a growing consensus among policymakers and academics that rules are better than discretion -both for democratic accountability and economic efficiency. Certainly the latter objective has been intellectually supported by modern macroeconomic theory shaped by the rational expectations revolution, the Lucas critique (Lucas, 1976), and the arguments in support of policy rules over discretion (Kydland and Prescott, 1977).

The evolution in macroeconomic regimes and policies is likely to have contributed to macroeconomic stabilization. After the Great Inflation period of the 1970s and 1980s (when industrial countries experienced abnormally persistent two-digit inflation rates and many developing countries lived through high and hyper-inflation episodes) came the Great Moderation that started in the late 1980s and early 1990s, leading most countries to converge to one-digit inflation rates at the start of the third millennium. If the Great Recession of 2007-2008 will mark a return to macroeconomic instability in the future or is only a footnote in the world's conquest of low inflation and overall macroeconomic stability is still to be seen. Moreover, the experience of this deep recession may put into question the usefulness of the dominant macroeconomic regimes and policies that have been adopted during the last decade.

Hence it is useful to take stock of the relations between macroeconomic regimes, policies, and outcomes observed in the world during the last decades. There is a growing but still partial empirical literature on the latter relations, which often shows ambiguous or non-robust results on the determinants of the choice of macroeconomic regimes, the effectiveness of macroeconomic policies in attaining their objectives, and the structural and policy-related drivers of macroeconomic outcomes.

Motivated by the open issues of the latter literature, and in close collaboration with several colleagues, I have carried out a research agenda that addresses the following questions:

(i) Which structural and performance-related variables determine the adoption of macroeconomic regimes, i.e., exchange-rate regimes, monetary regimes (money, inflation, and exchange-rate targets), and rule-based fiscal regimes?

(ii) What determines the success of macroeconomic policies in their countercyclical role and of monetary policy in attaining inflation targets?

(iii) Which structural and policy-related variables determine macroeconomic performance measured by growth levels, growth volatility, and inflation? 
In order to respond to the latter questions, this research agenda revisits and extends previous hypotheses on the empirical determinants of and interrelations between macroeconomic regimes, policies, and outcomes. We subject many behavioral hypotheses to empirical scrutiny for the largest possible world data base (covering more than 100 countries, with annual time series that extend, at most, from 1970 to 2008), and using a battery of frontier panel-data estimation techniques.

This paper summarizes the key results of this research agenda, without reporting the batteries of robustness tests for alternative specifications, estimation methods, and sub-samples that can be found in the 12 individual papers that comprise this project. I also abstract from a detailed review of related literature, presented in the individual papers.

Section 2 summarizes estimation methods and data used in this project. Then I turn to the main hypotheses and report empirical results on macroeconomic regime choice (section 3), success of macroeconomic policies (section 4), and macroeconomic performance (section 5). I conclude briefly in section 6 .

\section{Estimation Methods and Data}

The general estimation model for macroeconomic panels used in testing the empirical models encompasses the lagged dependent variable, two vectors of independent variables, interaction terms between sub-groups of independent variables, interaction terms between sub-groups of independent variables and group-specific dummy variables, and country and time effects:

$$
\begin{aligned}
\mathrm{y}_{\mathrm{i}, \mathrm{t}}= & \left.\mathrm{y}_{(\mathrm{i}, \mathrm{t}-1)}\right)^{\prime} \alpha+\mathrm{x}_{\mathrm{i}, \mathrm{t}}{ }^{\prime} \beta+\mathrm{z}_{\mathrm{i}, \mathrm{t}}{ }^{\prime} \gamma+\left(\mathrm{x}_{\mathrm{i}, \mathrm{t}, \mathrm{k}} \mathrm{z}_{\mathrm{i}, \mathrm{t}, \mathrm{q}}\right)^{\prime} \delta+\left(\mathrm{x}_{\mathrm{i}, \mathrm{t}} \otimes \mathrm{D}_{\mathrm{i}, \mathrm{t}}\right)^{\prime} \phi+ \\
& \left(\mathrm{z}_{\mathrm{i}, \mathrm{t}} \otimes \mathrm{D}_{\mathrm{i}, \mathrm{t}}\right)^{\prime} \lambda+\mathrm{u}_{\mathrm{i}}+\mathrm{v}_{\mathrm{t}}+\varepsilon_{\mathrm{i}, \mathrm{t}}
\end{aligned}
$$

where $y_{i t}$ is a continuous or discrete-choice dependent variable for macroeconomic regimes, policy outcomes or performance measures, $x_{i t}$ is a vector of exogenous variables, $z_{i t}$ is a vector of exogenous variables, $D_{i, t}$ is a vector of binary dummy variables that clusters independent variables into different country groups or time periods, $\mathrm{u}_{\mathrm{i}}$ is a country effect, $\mathrm{v}_{\mathrm{t}}$ is a time effect, and $\varepsilon_{\mathrm{i}, \mathrm{t}}$ is a stochastic error term. Possible interaction effects between exogenous variables are denoted by the vector product of $x_{i, t, k}$ and $z_{i, t . q}$, which are conforming sub-vectors of $x_{i, t}$ and $z_{i, t}$, respectively. In order to test in a nested way for differences in behavior across different country groups and/or different time periods, interaction effects between exogenous variables and binary country-group and time-period dummy variables, $\mathrm{D}_{\mathrm{i}, \mathrm{t}}$, are also introduced.

A large array of panel estimation techniques are used in the empirical research reported below. Linear estimation techniques are applied to continuous dependent variables, both for static and dynamic models. Non-linear models are used in the case of the following discrete-choice dependent variable techniques: random-effects probit and logit estimators, fixed-effects logit estimator, and fixed-effects instrumental-variable probit estimator. Finally, several models are used for dynamic specifications: Markov chain models, error-correction models, mean group and pooled mean group estimators (Pesaran et al., 1999), dynamic 
fixed effects estimators, generalized method of moment (GMM) estimators (Arellano and Bond, 1991) and system generalized method of moment estimators (SGMM) estimators (Arellano and Bover, 1995 and Blundell and Bond, 1998). Most estimators are applied to annual data frequencies, while GMM and SGMM are applied to data for five-year averages.

A large world database was assembled for this project from both publicly available and private databases. The project's database comprises a wide range of macroeconomic and financial variables, as well as qualitative/discrete institutional and economic-regime variables. Data coverage extends to at most 112 countries, with annual time series extending at most from 1970 to 2008 . The data used in each particular empirical model is a subset of the full data base, using only part of the country and time span mentioned above, typically reflected in panel sizes that extend from 287 to 2305 country-period observations.

\section{Choice of Macroeconomic Regimes}

I focus on three categories of macroeconomic regimes: exchange-rate (ER) systems (choice of ER regimes determined by the degree of ER flexibility), monetary regimes (selection of nominal anchors for the conduct of monetary policy), and rule-based fiscal regimes (choice of fiscal rules).

A world trend toward adoption of flexible ERs is observed since the mid1990s, as documented in Figure 1. Some countries may peg their currency to gain credibility and control of domestic inflation, while others may be more prone to float due to the larger exposure to real shocks. There is an empirical literature on the factors considered by countries in selecting their ER arrangements. Yet its results are not robust due to lack of consistent regime measures, small data samples, or limited use of alternative specifications and econometric techniques (Edison and Melvin, 1990; Juhn and Mauro 2002; Beker 2006).

In Calderón and Schmidt-Hebbel (2008a), we attempt to address the latter issues by using a sample of up to 110 countries with annual information over the period 1975-2005, using a de facto ER classification and a general specification that encompasses macroeconomic conditions, optimum currency area (OCA) conditions, and variables consistent with the financial approach (Levy-Yeyati, Sturzenegger, and Reggio 2006).

Representative results for the likelihood of having in place a non-flexible (fixed or intermediate) ER system are reported in Table 1. First, we find that countries with lower current-account surpluses (or higher deficits), little real ER misalignment, and higher inflation are more prone to adopt ER pegs. Second, factors associated with OCA conditions are good predictors of ER regimes: countries that are smaller in size, with higher trade openness, and larger correlation of domestic inflation with world inflation are more likely to peg their currencies. Finally, factors related to the financial approach are also significant determinants of ER regime choice: countries that exhibit more financial openness and higher financial development are more likely to adopt floating regimes.

Monetary regimes are defined by the choice of nominal anchors in the conduct of monetary policy: an ER target, a money growth target or an inflation target. Figure 2 reflects country distribution by explicit adoption of moneygrowth and inflation targets during 1975-2005; countries not counted there use 


\section{FIGURE 1}

NUMBER OF COUNTRIES BY EXCHANGE-RATE REGIMES, 1975-2005

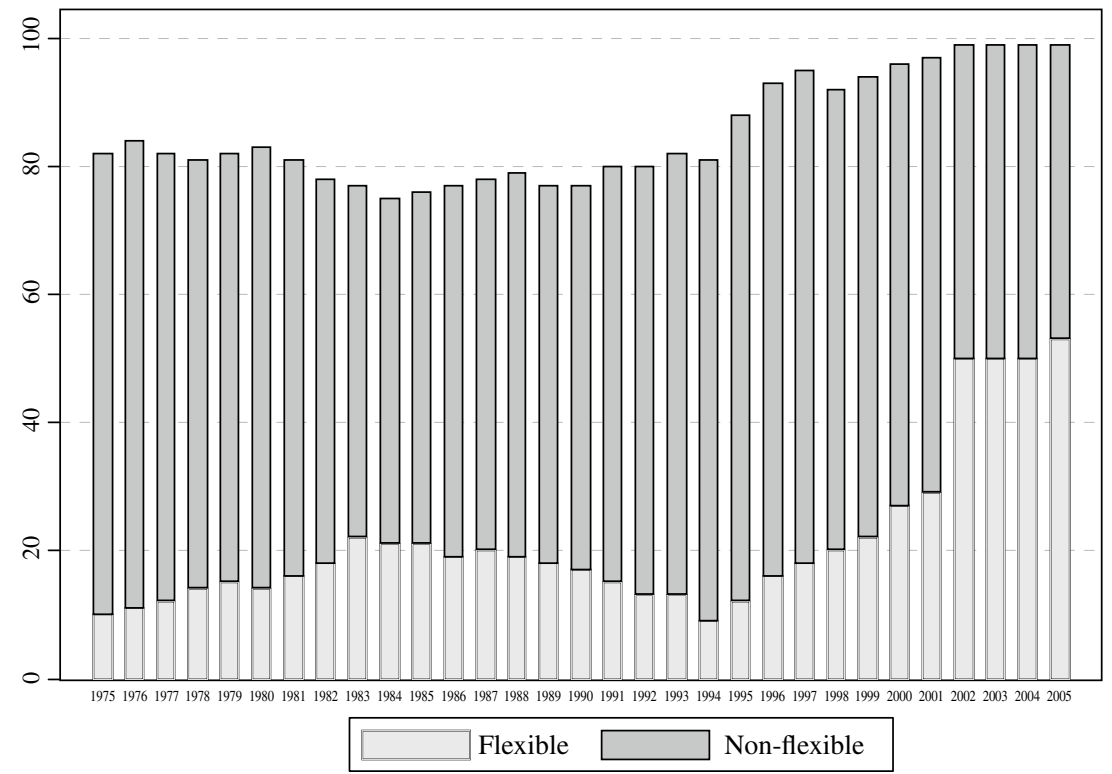

Source: Calderón and Schmidt-Hebbel (2008a).

Note: De-facto exchange rate regime classification. The non-flexible category encompasses intermediate and fixed exchange-rate regimes.

either ER anchors or no explicit unique nominal anchor. While the number of money-growth targeting (MGT) countries does not show any clear time trend, the number of inflation-targeting (IT) countries grows from one in 1990 to 25 in 2005. Next I refer to our estimation results for the likelihood of, first, having a MGT regime in place (against all other alternative explicit or implicit monetary regimes) and, second, having an IT regime in place (again, against all other monetary regimes).

In Calderón and Schmidt-Hebbel (2008b), we test for the likelihood of having MGT in place, using a sample of 55 countries with annual information covering 1975-2005. In the absence of any previous research on the choice of a moneygrowth target, we conduct our empirical research on the likelihood of having a MGT regime in place, identifying several structural variables that potentially affect the choice of MGT against alternative monetary regimes. Representative results are reported in Table 2. We find that the likelihood of having a MGT regime in place declines with monetary instability (which makes attainment of a money growth target more difficult), the government budget balance (which reduces the need for monetary financing of government deficits), domestic financial development (which may contribute both to larger monetary instability and the development of domestic public debt markets), and trade openness (which may contribute to weaker control of domestic money supply). 


\section{TABLE 1}

CHOICE OF EXCHANGE RATE REGIME

Dependent variable: dummy for the Exchange Rate Regime (flexible=0, fixed=1) Estimation methods: Discrete-choice logit panel-data models

Sample: 42-66 Countries, 1975-2005

\begin{tabular}{|c|c|c|}
\hline & Fixed Effects & Random Effects \\
\hline \multicolumn{3}{|l|}{ Macroeconomic conditions } \\
\hline Current account surplus & $\begin{array}{c}-9.228 * * * \\
(2.69)\end{array}$ & $\begin{array}{c}-10.091 * * * \\
(3.82)\end{array}$ \\
\hline Real exchange rate misalignment & $\begin{array}{c}-4.201 * * * \\
(2.83)\end{array}$ & $\begin{array}{c}-4.255 * * * \\
(3.74)\end{array}$ \\
\hline Inflation & $\begin{array}{c}7.626 * * * \\
(3.99)\end{array}$ & $\begin{array}{c}7.257 \text { *** } \\
(4.98)\end{array}$ \\
\hline \multicolumn{3}{|l|}{ OCA conditions } \\
\hline Trade openness & $\begin{array}{c}2.346 * * \\
(2.09)\end{array}$ & $\begin{array}{l}0.724 \\
(1.34)\end{array}$ \\
\hline Country size & $\begin{array}{c}-4.138 * * * \\
(3.51)\end{array}$ & $\begin{array}{c}-0.512 * * * \\
(3.41)\end{array}$ \\
\hline GDP per capita & $\begin{array}{l}2.879 \\
(1.61)\end{array}$ & $\begin{array}{c}0.402 * \\
(1.68)\end{array}$ \\
\hline Inflation correlation & $\begin{array}{c}2.253 * * * \\
\quad(6.14)\end{array}$ & $\begin{array}{c}2.429 * * * \\
(8.16)\end{array}$ \\
\hline \multicolumn{3}{|l|}{ Financial approach } \\
\hline Financial openness & $\begin{array}{c}-1.894 * * * \\
(3.77)\end{array}$ & $\begin{array}{c}-0.393 * * \\
(2.39) \\
-\end{array}$ \\
\hline Financial development & $\begin{array}{c}-4.372 * * * \\
(4.08)\end{array}$ & $\begin{array}{c}1.558 * * * \\
(3.00)\end{array}$ \\
\hline Constant & $\begin{array}{l}- \\
- \\
-\end{array}$ & $\begin{array}{c}10.732 * * * \\
(2.97)\end{array}$ \\
\hline Observations & 832 & 1365 \\
\hline Countries & 42 & 66 \\
\hline LR statistic & 270.9 & 203.1 \\
\hline $\mathrm{p}$-value & 0.00 & 0.00 \\
\hline
\end{tabular}

Note: Absolute value of $\mathrm{z}$ statistics in parentheses.

* Significant at $10 \%$; ** significant at 5\%; *** significant at $1 \%$. 
FIGURE 2

NUMBER OF COUNTRIES WITH MONEY-BASED AND INFLATION-TARGETING MONETARY REGIMES, 1975-2005

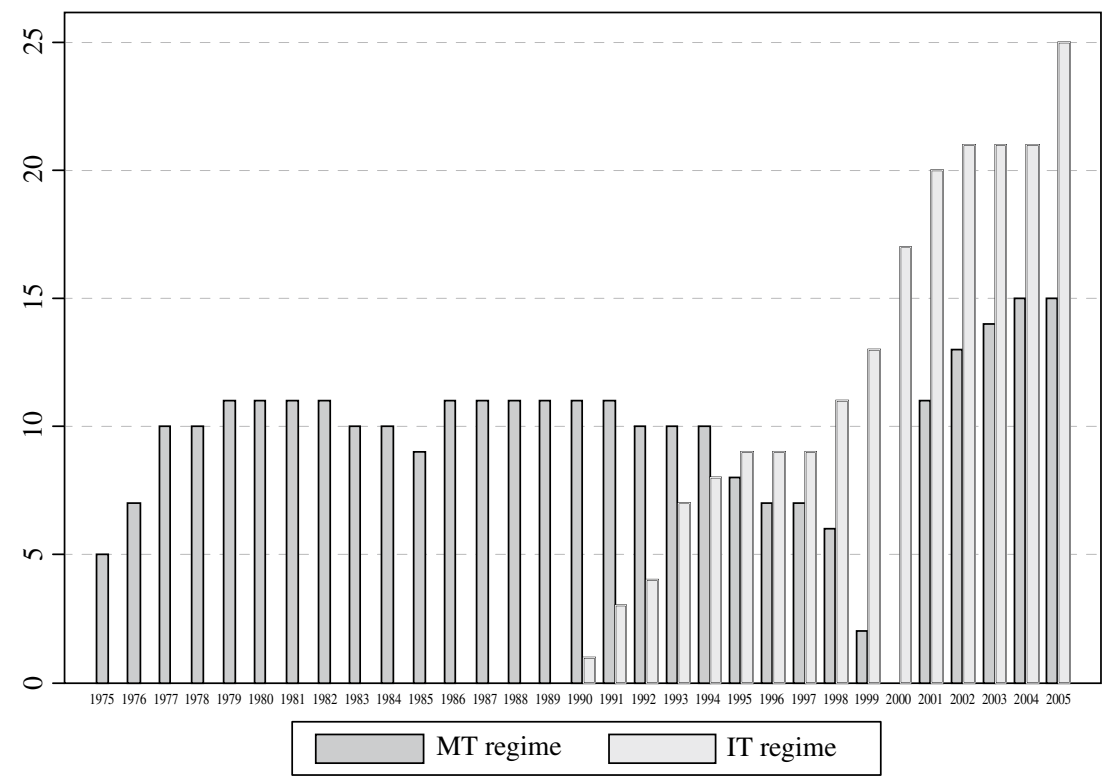

Source: Calderón and Schmidt-Hebbel (2008b).

IT has become the monetary policy framework of choice in many industrial and developing countries. Since the pioneering start of IT by New Zealand in 1990, 30 countries have switched to IT until 2009 (Schmidt-Hebbel, 2010). The early literature on IT identified pre-conditions that should be met at the time of IT adoption to ensure success of the new regime (Masson et al., 1997; Bernanke et al., 1999). Yet Batini and Laxton (2007) contradicted the preceding literature, showing that most inflation targeters (including most industrial-country inflation targeters) were far from satisfying the latter pre-conditions at the time they started IT. It took most IT countries many years after they started IT before putting in place economic and institutional conditions that characterize a fully-fledged IT regime.

The empirical literature on the likelihood of having IT in place has identified a limited number of potential determinants (e.g., Gerlach, 1999; Mishkin and Schmidt-Hebbel, 2002; Carare and Stone, 2003 and Hu, 2006). This literature presents several shortcomings, including narrow specifications, lack of robustness testing, lack of time dimension, and small sample size. In Calderón and Schmidt-Hebbel (2008c), we attempt to overcome the latter limitations by testing for a broad specification subject to a battery of estimation techniques and using a panel sample of up to 104 countries with annual information covering 1975-2005. 


\section{TABLE 2}

CHOICE OF MONEY GROWTH TARGETING REGIME

Dependent variable: dummy for Money Growth Targeting Regime (Money Growth Targeting=1; non-Money Growth Targeting $=0$ )

Estimation methods: Discrete-choice logit panel-data models

Sample: 22-55 Countries, 1975-2005

\begin{tabular}{|lccc|}
\hline & Fixed Effects & Pooled & Random Effects \\
\hline Financial development & $-0.936 * *$ & $0.285 * * *$ & $-1.542 * * *$ \\
& $(2.03)$ & $(2.85)$ & $(3.74)$ \\
Money instability (5 years) & $-0.64 * *$ & -0.054 & $-0.282 * *$ \\
& $(2.24)$ & $(1.39)$ & $(2.27)$ \\
Government budget balance & $-13.932 * * *$ & $4.987 * * *$ & $-8.699 * * *$ \\
& $(2.88)$ & $(4.65)$ & $(2.95)$ \\
GDP per capita & - & - & - \\
& - & - & - \\
Trade openness & $-2.234 * *$ & $-1.108 * * *$ & $-2.044 * *$ \\
& $(1.99)$ & $(6.87)$ & $(2.54)$ \\
Constant & $1.675 * * *$ & $-0.400 * * *$ & 0.029 \\
& $(2.70)$ & $(3.13)$ & $(0.04)$ \\
\hline Observations & 473 & 1096 & 1096 \\
Countries & 22 & 55 & 55 \\
Countries with a MGT regime & 22 & 22 & 22 \\
Countries without a MGT regime & 0 & 33 & 33 \\
(control group) & & & 38.32 \\
LR statistic & 39.53 & 95.59 & 0.00 \\
p-value & 0.00 & 0.00 & \\
\hline
\end{tabular}

Note: Absolute value of $\mathrm{z}$ statistics in parentheses.

* Significant at $10 \%$; ** significant at $5 \%$; *** significant at $1 \%$.

A representative set of results for the determinants of the likelihood of having IT in place is reported in Table 3 . Among usually mentioned prerequisites for IT, we find that lower inflation (an acceptable degree of monetary stabilization), a higher government budget balance (which reduces the need for fiscal dominance over monetary policy), and a flexible exchange-rate regime (the absence of a competing nominal anchor for monetary policy) raise significantly the likelihood or having in place an IT regime. Domestic financial development and trade openness also contribute to raise the likelihood of IT. Finally, IT is more likely to be implemented in richer countries.

The absence of adequate fiscal rules during the boom years that preceded the recent global financial crisis and the subsequent fiscal response to the crisis 


\section{TABLE 3}

CHOICE OF INFLATION TARGETING REGIME

Dependent variable: dummy for the Inflation Targeting Regime (Inflation Targeting=1; nonInflation Targeting=0)

Estimation methods: Discrete-choice logit panel-data models

Sample: 19-98 Countries, 1975-2005

\begin{tabular}{|c|c|c|c|c|}
\hline \multirow[b]{2}{*}{ Inflation } & \multicolumn{2}{|c|}{ Fixed Effects } & \multicolumn{2}{|c|}{ Random Effects } \\
\hline & $\begin{array}{c}-130.026 * * * \\
(2.95)\end{array}$ & $\begin{array}{c}-117.311 * * * \\
(3.18)\end{array}$ & $\begin{array}{c}-36.421 * * * \\
\quad(5.88)\end{array}$ & $\begin{array}{c}-39.508 * * * \\
\quad(6.63)\end{array}$ \\
\hline Government budget balance & $\begin{array}{l}-25.066 \\
(1.45)\end{array}$ & $\begin{array}{l}- \\
-\end{array}$ & $\begin{array}{c}17.909 * * \\
(2.53)\end{array}$ & - \\
\hline Financial development & $\begin{array}{l}19.872 * * * \\
\quad(3.07)\end{array}$ & $\begin{array}{c}16.881 * * * \\
(3.39)\end{array}$ & $\begin{array}{c}3.186 * * * \\
(3.40)\end{array}$ & $\begin{array}{l}2.633 * * * \\
(2.99)\end{array}$ \\
\hline Exchange rate regime & $\begin{array}{l}-20.320 * * * \\
(3.03)\end{array}$ & $\begin{array}{c}-17.824 * * * \\
\quad(3.22)\end{array}$ & $\begin{array}{c}-4.464 * * * \\
\quad(7.20)\end{array}$ & $\begin{array}{c}-3.990 * * * \\
\quad(7.74)\end{array}$ \\
\hline GDP per capita & $\begin{array}{l}104.027^{* * * *} \\
(3.19)\end{array}$ & $\begin{array}{c}90.130 * * * \\
\quad(3.56)\end{array}$ & $\begin{array}{l}3.478 * * * \\
(3.49)\end{array}$ & $\begin{array}{l}4.822 * * * \\
\quad(5.90)\end{array}$ \\
\hline Trade openness & $\begin{array}{l}46.763 * * * \\
(2.83)\end{array}$ & $\begin{array}{c}42.343 * * * \\
\quad(3.03)\end{array}$ & $\begin{array}{l}0.837 \\
(0.68)\end{array}$ & $\begin{array}{c}3.185 * * * \\
(4.01)\end{array}$ \\
\hline $\begin{array}{l}\text { Dummy for Latin American } \\
\text { Countries }\end{array}$ & $\begin{array}{l}- \\
-\end{array}$ & $\begin{array}{l}- \\
-\end{array}$ & $\begin{array}{l}- \\
-\end{array}$ & $\begin{array}{c}7.433 * * * \\
(4.85)\end{array}$ \\
\hline Constant & $\begin{array}{l}- \\
-\end{array}$ & $\begin{array}{l}- \\
-\end{array}$ & $\begin{array}{c}-30.343 * * * \\
(3.44)\end{array}$ & $\begin{array}{c}-47.961 * * * \\
\quad(7.01)\end{array}$ \\
\hline Observations & 491 & 554 & 1854 & 2305 \\
\hline Countries & 19 & 24 & 76 & 98 \\
\hline Countries with a IT regime & 19 & 24 & 19 & 24 \\
\hline $\begin{array}{l}\text { Countries without a IT regime } \\
\text { (control group) }\end{array}$ & 0 & 0 & 57 & 74 \\
\hline LR statistic & 450.19 & 499.19 & 126.90 & 177.77 \\
\hline p-value & 0.00 & 0.00 & 0.00 & 0.00 \\
\hline
\end{tabular}

Note: Absolute value of $\mathrm{z}$ statistics in parentheses.

$*$ Significant at $10 \%$; ** significant at $5 \%$; *** significant at $1 \%$.

and recession in the U.S., as well as the repeated failures of the fiscal rule based on the Stability and Growth Pact (SGP) in the EU, explain the new worldwide support to stronger fiscal rules in order to support fiscal sustainability and counter-cyclical fiscal policy (e.g., Bernanke, 2010 for the U.S.). Now a growing number of countries are planning to reform their fiscal policy regimes, adopting explicit fiscal rules aimed at contributing to stabilize more effectively business cycles and make public finances more resilient to political pressure. 
In fact, before the global crisis - and still now- only a minority of countries had in place a fiscal regime based on an explicit fiscal rule. Figure 3 depicts the time trend of the number of countries with a fiscal rule in place during 1975-2005: the number has risen steadily since 3 countries during most of the 1970s and 1980s, showing a significant increase with the Maastricht (or SGP) conditions for prospective euro zone members in 1997, and climbing to a world total of 30 countries in 2005.

What determines the adoption of fiscal rules? The study of possible macroeconomic and institutional determinants behind the choice of a fiscal regime has been an unexplored area. In Calderón and Schmidt-Hebbel (2008d) we attempt to fill this void by providing an assessment of the determinants of the likelihood of adopting and holding to fiscal rules that constrain the exercise of fiscal policy. We test for a broad specification subject to a battery of panel-data estimation techniques and using a panel sample of 75 countries (of which at most 24 had a fiscal rule in place) with annual information covering 1975-2005. Representative results for the determinants of the likelihood of having a rule-based fiscal regime in place are summarized in Table 4. On one hand, fiscal policy strength (measured by the government budget balance) and government stability (reflected by International Country Risk Guide-ICRG- measures of governments' abilities to stay in office and carry out their programs) are significant in determining adop-

FIGURE 3

NUMBER OF COUNTRIES WITH RULE-BASED FISCAL REGIMES, 1975-2005

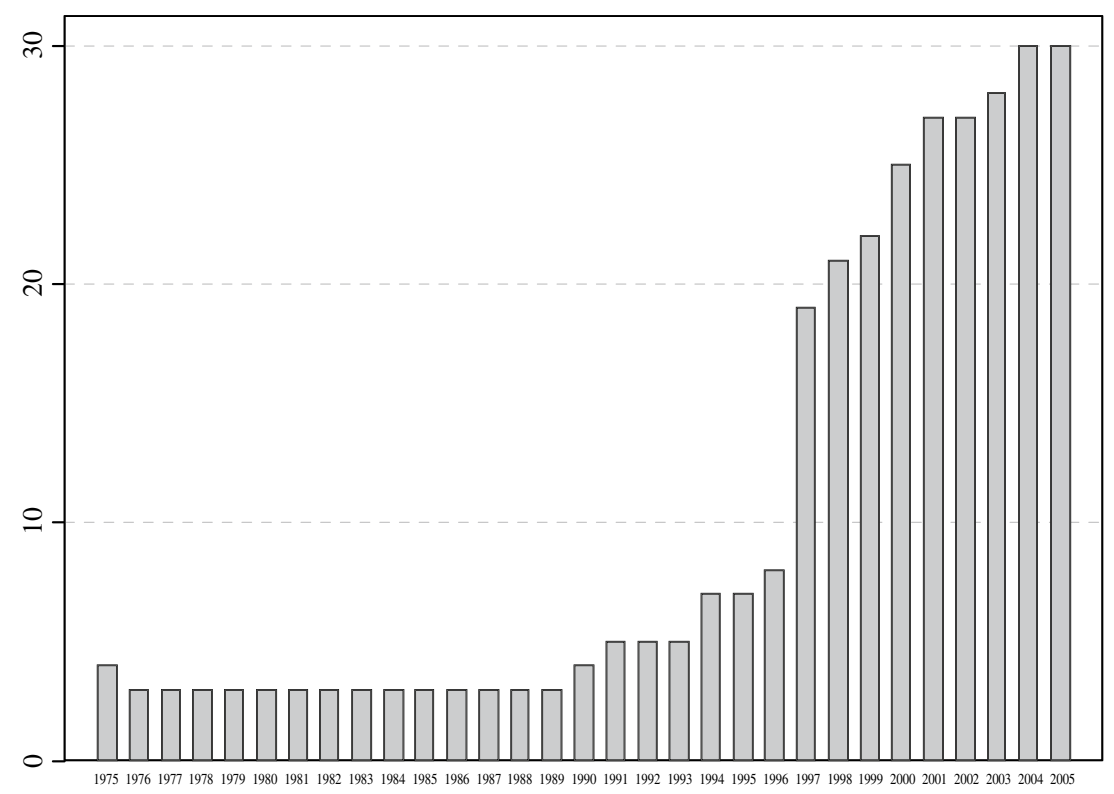

Source: Calderón and Schmidt-Hebbel (2008d). 


\section{TABLE 4}

CHOICE OF RULE-BASED FISCAL REGIME

Dependent variable: dummy for rule-based fiscal regime (rule-based regime $=1$, other regime $=0$ ) Estimation methods: Discrete-choice panel data models

Sample: 24-75 Countries, 1975-2005

\begin{tabular}{|c|c|c|c|c|c|c|}
\hline \multirow[b]{2}{*}{ Government budget balance } & \multicolumn{3}{|c|}{ Fixed Effects } & \multicolumn{3}{|c|}{ Random Effects } \\
\hline & $\begin{array}{l}0.174 \\
(0.03)\end{array}$ & $\begin{array}{l}1.732 \\
(0.25)\end{array}$ & $\begin{array}{l}35.365 * * * \\
\quad(6.79)\end{array}$ & $\begin{array}{r}8.337 \\
(1.29)\end{array}$ & $\begin{array}{c}11.785 * \\
(1.87)\end{array}$ & $\begin{array}{c}36.811 * * * \\
\quad(7.15)\end{array}$ \\
\hline Dependency ratio & $\begin{array}{c}-54.833 * * * \\
\quad(5.05)\end{array}$ & $\begin{array}{l}-57.268 * * * \\
(5.33)\end{array}$ & $\begin{array}{l}-51.562 * * * \\
\quad(7.94)\end{array}$ & $\begin{array}{c}-42.595 * * * \\
(5.37)\end{array}$ & $\begin{array}{l}-45.096 * * * \\
\quad(7.04)\end{array}$ & $\begin{array}{c}-45.996 * * * \\
\quad(7.59)\end{array}$ \\
\hline Expenditure procyclicality (10 years) & $\begin{array}{c}-2.18 * * \\
(2.38)\end{array}$ & $\begin{array}{c}-1.990 * * \\
(2.20)\end{array}$ & $\begin{array}{c}-1.531 * * * \\
(3.23)\end{array}$ & $\begin{array}{c}-2.195 * * * \\
(2.84)\end{array}$ & $\begin{array}{c}-1.945 * * \\
(2.51)\end{array}$ & $\begin{array}{c}-1.362 * * * \\
(2.89)\end{array}$ \\
\hline Government stability & $\begin{array}{l}0.149 \\
(1.27)\end{array}$ & - & $\begin{array}{c}0.357 * * * \\
(4.40)\end{array}$ & $\begin{array}{c}0.262 * * \\
(2.38)\end{array}$ & - & $\begin{array}{c}0.377 * * * \\
(4.59)\end{array}$ \\
\hline GDP per capita & $\begin{array}{c}30.011^{* * *} \\
\quad(7.50)\end{array}$ & $\begin{array}{l}31.507 * * * * \\
(7.81)\end{array}$ & - & $\begin{array}{c}23.33 * * * \\
(17.36)\end{array}$ & $\begin{array}{c}24.688 * * * \\
(17.77)\end{array}$ & $\begin{array}{l}- \\
-\end{array}$ \\
\hline Constant & - & - & - & $\begin{array}{l}-209.577 * * * * \\
(14.47)\end{array}$ & $\begin{array}{c}-217.869 * * * \\
(14.65)\end{array}$ & $\begin{array}{c}18.109 * * * \\
(5.35)\end{array}$ \\
\hline Observations & 712 & 712 & 712 & 2005 & 2055 & 2005 \\
\hline Countries & 24 & 24 & 24 & 75 & 75 & 75 \\
\hline Countries with a rule-based fiscal regime & 24 & 24 & 24 & 24 & 24 & 24 \\
\hline $\begin{array}{l}\text { Countries without rule-based fiscal regime } \\
\text { (control group) }\end{array}$ & 0 & 0 & 0 & 51 & 51 & 51 \\
\hline LR statistic & 529.3 & 527.7 & 310.4 & 477.3 & 604.0 & 113.8 \\
\hline p-value & 0.00 & 0.00 & 0.00 & 0.00 & 0.00 & 0.00 \\
\hline
\end{tabular}

Note: Absolute value of $\mathrm{z}$ statistics in parentheses.

* Significant at $10 \%$; ** significant at $5 \%$; *** significant at $1 \%$.

tion of fiscal rules. On the other hand, high population shares of young and old people (high dependency ratios), which add pressure on government budgets, and pro-cyclical government expenditure behavior, are significant deterrents to adopting fiscal rules. Richer countries are more likely to adopt fiscal rules than poorer nations. Therefore our results suggest that countries invest significantly in institutional conditions that affect fiscal policy execution and performance when adopting and having in place fiscal rules.

\section{Success of Macroeconomic Policies}

Now I turn to the determinants of success (or lack thereof) of macroeconomic policies. I focus selectively on two dimensions of macroeconomic policy performance: cyclicality of both fiscal and monetary policies and accuracy of monetary policy in attaining inflation targets.

Macroeconomic policies are geared in principle toward stabilizing businesscycle fluctuations. There is evidence on the ability of industrial economies to 
conduct counter-cyclical fiscal policies (e.g., Lane, 2003a, b; Alesina et al., 2008). However, in contrast to industrial economies, earlier research suggested that monetary and fiscal policies were predominantly pro-cyclical, both in Latin America and other developing regions (Hausmann and Stein, 1996; Gavin and Perotti, 1997a; Gavin and Hausmann, 1998; Talvi and Végh, 2005; Lane, 2003a; Kaminsky et al., 2004).

Developing economies comprise a highly heterogeneous country group that exhibits large differences in policy credibility, institutional development, and financial depth. Previous work has established empirically that policy credibility and institutional development contribute significantly to macroeconomic policy cyclicality in emerging economies (Calderón and Schmidt-Hebbel, 2003 and Calderón et al., 2004). The latter research shows that fiscal and macroeconomic policy are (independently) more likely to follow a counter-cyclical stance when country risk premiums are lower and institutions are more developed.

In Calderón et al. (2010), we broaden our previous research significantly by extending it to 112 countries over 1984-2008, testing for several specifications and using several panel-data estimation techniques. Selective results are reported in Tables 5 and 6 . The results for the extended Taylor equation for the monetary policy rate reflect a significant positive interaction effect between the output gap and ICRG's aggregate measure of institutional quality (Table 5). The results imply that when countries display high (low) levels of institutional quality, monetary policy acts counter- (pro-) cyclically. Analogous results are obtained for fiscal policy, reflecting a significant negative interaction effect between government spending and the output gap (Table 6). These results imply that countries where institutional development is high (low), government spending follows a counter- (pro-) cyclical pattern. In sum, the quality of institutions, not the dividing line between industrial and emerging economies, explains the cyclical pattern of macroeconomic policies in the world.

It has also been argued that political systems with multiple fiscal veto points (highly correlated with democracy) are more likely to exhibit fiscal policy pro-cyclicality (Stein et al., 1999; Braun, 2001; Talvi and Végh, 2005) and that limited access to domestic and international financial markets hinders the ability of governments to pursue counter-cyclical fiscal policy (Gavin, Hausmann, Perotti and Talvi 1996, Caballero and Krishnamurthy 2004, Riascos and Végh 2004). Therefore we extend our study of fiscal policy cyclicality in Calderón and Schmidt-Hebbel (2008e) by adding further potential determinants: the extent of democracy and measures of domestic financial depth and international financial integration. We subject the latter hypothesis to a large array of estimation techniques based on alternative specifications applied to different fiscal policy measures, using a large data sample covering 90 countries during 1970-2005.

Selective results are reported in Table 7. They show that the budget balance ratio to GDP behaves pro-cyclically in countries with (independently) low levels of external financial openness, low domestic financial depth, low institutional quality, and/or democratic regimes. As the significant interaction effects between the latter variables and the output gap reflect, the opposite is true in countries that are highly developed -both financially and institutionally- and countries 


\section{TABLE 5}

CYCLICALITY OF MONETARY POLICY

Dependent Variable: Nominal Interest Rate Deviation from Long-run Value

Estimation Method: GMM-Instrumental Variables

Sample: 84 Countries, 1984-2007

\begin{tabular}{|lcc|}
\hline & $\begin{array}{c}\text { GMM } \\
\text { Hodrick-Prescott } \\
\text { Filter }\end{array}$ & $\begin{array}{c}\text { GMM } \\
\text { First-Difference } \\
\text { Filter }\end{array}$ \\
\hline Lagged dependent variable & -0.281 & -0.271 \\
& $(0.000)$ & $(0.000)$ \\
Inflation Rate deviation from Long-run value & 0.367 & 0.339 \\
& $(0.000)$ & $(0.000)$ \\
Output Gap & -0.632 & -0.559 \\
& $(0.000)$ & $(0.000)$ \\
Output Gap * Institutional Quality & 0.009 & 0.009 \\
& $(0.001)$ & $(0.002)$ \\
\hline Observations & 1336 & 1252 \\
Countries & 84 & 84 \\
Sargan-Statistic (p-value) & 0.089 & 0.145 \\
\hline
\end{tabular}

Note: p-values reported in parenthesis. Hodrick-Prescott and First Difference filters were used to extract the cyclical components of the dependent variable, inflation, currency depreciation, and output.

\section{TABLE 6}

CYCLICALITY OF FISCAL POLICY I

Dependent Variable: Government Spending Deviations from its long-Run Value Estimation Method: GMM-Instrumental Variables

Sample: 112 Countries, 1984-2008

\begin{tabular}{|lcc|}
\hline & $\begin{array}{c}\text { GMM } \\
\text { Hodrick-Prescott } \\
\text { Filter }\end{array}$ & $\begin{array}{c}\text { GMM } \\
\text { First-Difference } \\
\text { Filter }\end{array}$ \\
\hline Lagged dependent variable & 0.147 & -0.098 \\
& $(0.000)$ & $(0.000)$ \\
Output Gap & 1.649 & 1.546 \\
& $(0.000)$ & $(0.000)$ \\
Output Gap * Institutional Quality & -0.020 & -0.017 \\
& $(0.000)$ & $(0.000)$ \\
\hline Observations & 2269 & 2157 \\
Countries & 112 & 112 \\
Sargan-Statistic (p-value) & 0.137 & 0.453 \\
\hline
\end{tabular}

Note: p-values reported in parenthesis. Hodrick-Prescott and First Difference filters were used to extract the cyclical components of the dependent variable and output. 


\section{TABLE 7}

CYCLICALITY OF FISCAL POLICY II

Dependent Variable: Fiscal Indicator (as percentage of GDP, in log differences)

Estimation Method: Panel Instrumental Variables ${ }^{1}$

Sample: 83-90 Countries, 1970-2005

\begin{tabular}{|c|c|c|c|}
\hline & $\begin{array}{l}\text { Budget } \\
\text { Balance }\end{array}$ & Revenue & Expenditure \\
\hline $\begin{array}{l}\text { Real Output Growth } \\
\text { (in log differences) }\end{array}$ & $\begin{array}{c}-2.061 * * \\
(0.87)\end{array}$ & $\begin{array}{l}2.557 \\
(2.74)\end{array}$ & $\begin{array}{l}11.431 * * \\
(3.93)\end{array}$ \\
\hline $\begin{array}{l}\text { Real Output Growth } x \text { Financial Openness } \\
\text { (FO: Foreign liabilities as \% GDP, logs) }\end{array}$ & $\begin{array}{c}0.174 * * \\
(0.08)\end{array}$ & $\begin{array}{c}-0.220 \\
(0.27)\end{array}$ & $\begin{array}{l}-0.953 * * \\
\quad(0.36)\end{array}$ \\
\hline $\begin{array}{l}\text { Real Output Growth } x \text { Financial Depth } \\
\text { (FD: Dom. Credit to Private Sector as } \% G D P \text {, logs) }\end{array}$ & $\begin{array}{c}0.133 * * \\
(0.06)\end{array}$ & $\begin{array}{l}-0.221 \\
(0.24)\end{array}$ & $\begin{array}{l}-0.811 * * \\
\quad(0.27)\end{array}$ \\
\hline $\begin{array}{l}\text { Real Output Growth } x \text { Institutional Quality } \\
\text { (IQ: ICRG Index of Political Risk) }\end{array}$ & $\begin{array}{c}0.017 * * \\
(0.01)\end{array}$ & $\begin{array}{l}-0.016 \\
(0.01)\end{array}$ & $\begin{array}{c}-0.087 * * \\
(0.03)\end{array}$ \\
\hline $\begin{array}{l}\text { Real Output Growth } x \text { Democracy } \\
\text { (Democracy: Polity Score) }\end{array}$ & $\begin{array}{l}-0.023 * * \\
\quad(0.01)\end{array}$ & $\begin{array}{l}0.035 \\
(0.02)\end{array}$ & $\begin{array}{c}0.135 * * \\
(0.05)\end{array}$ \\
\hline $\begin{array}{l}\text { Fiscal indicator, lagged } \\
\text { (\% of GDP, in log differences) }\end{array}$ & $\begin{array}{l}-0.250 * * \\
\quad(0.03)\end{array}$ & $\begin{array}{l}-0.145 * * \\
\quad(0.02)\end{array}$ & $\begin{array}{l}-0.135 * * \\
\quad(0.03)\end{array}$ \\
\hline $\begin{array}{l}\text { Terms of trade, lagged } \\
\text { (in logs) }\end{array}$ & $\begin{array}{c}-0.002 \\
(0.01)\end{array}$ & $\begin{array}{c}0.117 * * \\
(0.02)\end{array}$ & $\begin{array}{c}0.087 * * \\
(0.03)\end{array}$ \\
\hline $\begin{array}{l}\text { War Dummy } \\
\text { (Dummy }=1 \text { if internal or external war) }\end{array}$ & $\begin{array}{c}-0.009 * * \\
(0.00)\end{array}$ & $\begin{array}{l}0.000 \\
(0.001)\end{array}$ & $\begin{array}{l}0.025 * \\
(0.02)\end{array}$ \\
\hline Observations & 1983 & 1882 & 2051 \\
\hline Countries & 90 & 83 & 90 \\
\hline Adjusted $\mathrm{R}^{2}$ & 0.146 & 0.135 & 0.253 \\
\hline
\end{tabular}

1 We instrument real output growth with lagged values of real output growth, current and lagged terms of trade changes, current and lagged growth in external demand, current and lagged changes in foreign interest rates.

Note: * significant at $10 \%$; ** significant at $5 \%$; *** significant at $1 \%$. Numbers in parenthesis represent the autocorrelation and heteroskedasticity consistent standard errors.

with non-democratic regimes. Looking behind the government balance, next we test separately for the cyclical properties of government revenue and expenditure ratios to GDP. The results are surprising as they show that all the cyclical properties of the budget balance are driven by the cyclical properties of the expenditure ratio to GDP, none by the revenue ratio. In fact, the revenue ratio to GDP is a-cyclical and no interaction term appears to be significantly different from zero. By contrast, the cyclical term and all interaction effects are highly significant determinants of the government expenditure ratio to GDP - like in 
the case of the government balance ratio, but obviously exhibiting opposite signs. We conclude that government expenditure - which is largely discretionary in most countries - drives the cyclical stance of government balances in the world, and its cyclical pattern is shaped by financial openness, financial depth, institutional quality, and the political regime.

Monetary policy success hinges on consistent central bank behavior and strong private-sector credibility. As discussed above, a rising number of central banks is aiming at stronger credibility and improved monetary policy effectiveness by committing to explicit inflation targets. Have the latter banks succeeded in meeting their targets and what explains their success - or lack thereof? In Albagli and Schmidt-Hebbel (2008), we address the latter questions by measuring IT performance in the world population of IT countries, identifying the role of fundamental determinants and measures of institutional and macroeconomic performance in the success (or lack thereof) in meeting inflation targets, controlling for external and domestic shocks. We apply several panel-data estimation techniques to different specifications for inflation misses (the absolute deviation of inflation rates from official target levels), based on quarterly 1990-2003 data for the world sample of inflation-targeting countries. Selective results are reported in Table 8 .

We control for several variables that account for part of the variance of inflation misses, including current and lagged values of oil price shocks and nominal exchange-rate shocks. Our two fundamental variables are central bank independence (a potentially key institutional factor driving monetary independence) and macroeconomic credibility (proxied by sovereign debt premiums). Both latter variables are significant determinants. Central bank independence lowers annualized inflation deviations from targets by some 20 basis points and a 100-point reduction in sovereign country risk spreads reduces inflation misses by some 10 basis points.

\section{Macroeconomic Performance}

Now I turn to the determinants of macroeconomic performance measures. I focus selectively on two key macroeconomic indicators: economic growth (both its level and volatility measures) and inflation.

Trade and financial openness and integration have exploded in the world at large and its major regions since the 1970s (Figures 4 and 5). A growing body of empirical literature has focused on the contribution of trade and financial openness on country growth levels, with ambiguous results. This motivated a fresh look at the evidence on the links between economic growth, external openness, and foreign shocks (trade and financial shocks; price and quantity shocks) in a large world panel sample, presented in Calderón, Loayza, and Schmidt-Hebbel (2006). There we reported that trade and financial openness (or integration) contribute positively and significantly to growth, controlling for four types of external shocks and domestic growth determinants. Moreover, there we provided evidence that financial integration reduces the sensitivity of growth to foreign shocks, while trade integration magnifies or dampens foreign shocks, depending on the type of shock. 


\section{TABLE 8}

DEVIATION OF INFLATION RATES FROM INFLATION TARGETS

Dependent Variable: Absolute Deviation of Inflation from Inflation Target (percentage points) Estimation Method: OLS and Fixed-Effects

Sample: 19 Countries, 1990-2003 (quarterly data)

\begin{tabular}{|c|c|c|c|c|}
\hline & \multicolumn{2}{|c|}{ Full sample } & \multicolumn{2}{|c|}{$\begin{array}{c}\text { Stationary inflation } \\
\text { sub-sample }\end{array}$} \\
\hline & OLS & $\begin{array}{l}\text { Fixed } \\
\text { Effects }\end{array}$ & OLS & $\begin{array}{l}\text { Fixed } \\
\text { Effects }\end{array}$ \\
\hline C & $\begin{array}{c}0.255 \\
(0.001)\end{array}$ & $\begin{array}{c}0.340 \\
(0.008)\end{array}$ & $\begin{array}{c}0.090 \\
(0.335)\end{array}$ & $\begin{array}{c}0.215 \\
(0.080)\end{array}$ \\
\hline Dependent variable $(-1)$ & $\begin{array}{c}0.855 \\
(0.000)\end{array}$ & $\begin{array}{c}0.788 \\
(0.000)\end{array}$ & $\begin{array}{c}1.012 \\
(0.000)\end{array}$ & $\begin{array}{c}0.952 \\
(0.000)\end{array}$ \\
\hline Dependent variable $(-2)$ & $\begin{array}{l}-0.192 \\
(0.006)\end{array}$ & $\begin{array}{l}-0.166 \\
(0.014)\end{array}$ & $\begin{array}{l}-0.301 \\
(0.000)\end{array}$ & $\begin{array}{l}-0.285 \\
(0.001)\end{array}$ \\
\hline Dependent variable $(-3)$ & $\begin{array}{l}-0.080 \\
(0.118)\end{array}$ & $\begin{array}{c}-0.142 \\
(0.006)\end{array}$ & $\begin{array}{l}-0.043 \\
(0.500)\end{array}$ & $\begin{array}{l}-0.104 \\
(0.111)\end{array}$ \\
\hline Nominal Exchange Rate Variation $(-1)$ & $\begin{array}{c}0.007 \\
(0.146)\end{array}$ & $\begin{array}{c}0.004 \\
(0.428)\end{array}$ & $\begin{array}{c}0.012 \\
(0.027)\end{array}$ & $\begin{array}{c}0.006 \\
(0.362)\end{array}$ \\
\hline Oil Price trend deviation & $\begin{array}{c}0.007 \\
(0.024)\end{array}$ & $\begin{array}{c}0.007 \\
(0.039)\end{array}$ & $\begin{array}{c}0.014 \\
(0.001)\end{array}$ & $\begin{array}{c}0.013 \\
(0.002)\end{array}$ \\
\hline Oil Price trend deviation $(-1)$ & $\begin{array}{l}-0.008 \\
(0.035)\end{array}$ & $\begin{array}{l}-0.008 \\
(0.037)\end{array}$ & $\begin{array}{l}-0.014 \\
(0.009)\end{array}$ & $\begin{array}{l}-0.013 \\
(0.012)\end{array}$ \\
\hline Oil Price trend deviation $(-2)$ & $\begin{array}{c}0.007 \\
(0.022)\end{array}$ & $\begin{array}{c}0.006 \\
(0.049)\end{array}$ & $\begin{array}{c}0.009 \\
(0.044)\end{array}$ & $\begin{array}{c}0.007 \\
(0.093)\end{array}$ \\
\hline Central Bank Independence & $\begin{array}{l}-0.204 \\
(0.003)\end{array}$ & - & $\begin{array}{l}-0.260 \\
(0.004)\end{array}$ & - \\
\hline Sovereign Spread Premium & $\begin{array}{c}0.069 \\
(0.001)\end{array}$ & $\begin{array}{c}0.119 \\
(0.030)\end{array}$ & $\begin{array}{c}0.128 \\
(0.000)\end{array}$ & $\begin{array}{c}0.135 \\
(0.000)\end{array}$ \\
\hline Observations & 358 & 358 & 287 & 287 \\
\hline Countries & 19 & 19 & 11 & 11 \\
\hline Adjusted $\mathrm{R}^{2}$ & 0.53 & 0.55 & 0.81 & 0.82 \\
\hline
\end{tabular}

Note: p-values reported in parenthesis. Lag number identified for each independent variable in parenthesis.

In subsequent work, Elbadawi, Kaltani, and Schmidt-Hebbel (2008) assess the effects of civil wars, foreign aid, and real ER misalignment on growth in a world sample of 77 countries during the 1970-2004 period, using the system GMM-IV estimator. Selective results are reported in Table 9. Standard control variables found in the empirical panel growth literature are included here, among which I only mention the significant negative influence of inflation on growth. 


\section{FIGURE 4}

TRADE OPENNESS IN THE WORLD AND BY REGIONS, 1975-2005

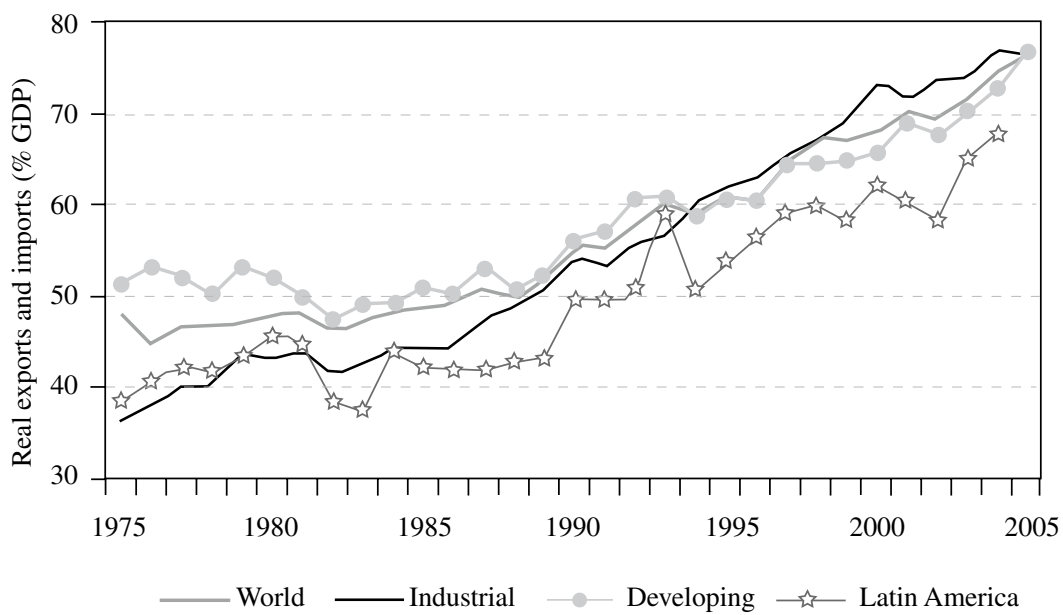

Source: Calderón and Schmidt-Hebbel (2008f).

FIGURE 5

FINANCIAL OPENNESS IN THE WORLD AND BY REGIONS, 1975-2005

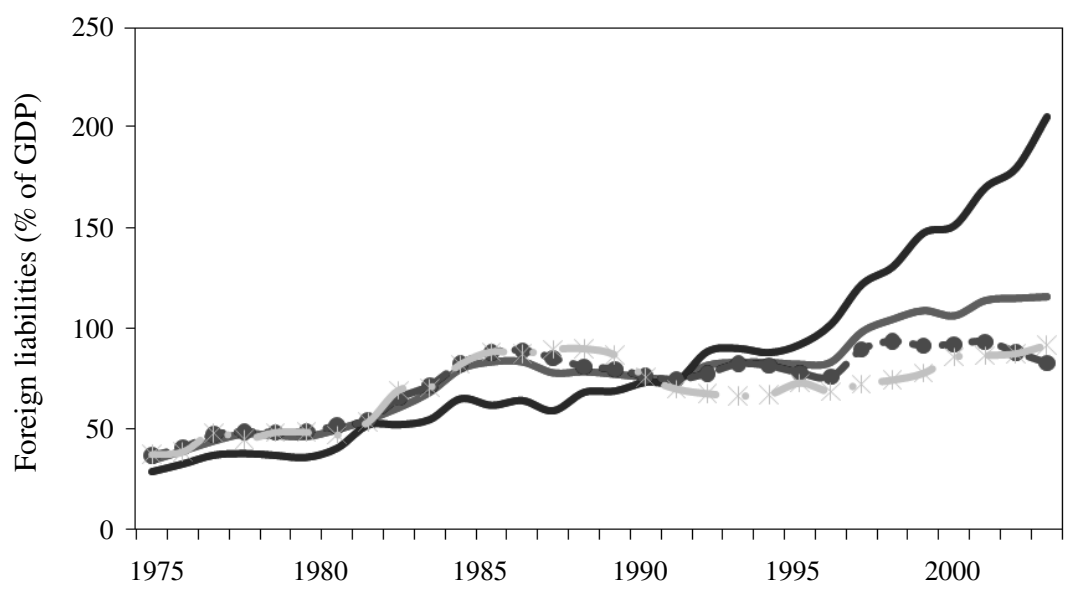

World Industrial _- - Developing L Latin America

Source: Calderón and Schmidt-Hebbel (2008f). 
Not surprisingly, peace onset and post-conflict periods affect growth. Foreign aid has a highly non-monotonic and significant effect on growth: low to moderate aid flows (relative to recipients' GDP level) raise growth while large aid flows reduce growth. Real ER misalignment (measured as real ER overvaluation) reduces growth. Financial development raises growth directly and, in addition, dampens the negative growth effect of ER overvaluation (as captured by their positive significant interaction effect). Moreover, real ER overvaluation interacts negatively with foreign aid, therefore reducing the positive effects of moderate aid flows and exacerbating the negative effects of large aid flows.

Now I shift to subsequent work on the influence of openness on the second moment of growth. In Calderón et al. (2008), we focus on the determinants of the standard deviation of GDP growth using the GMM system estimator applied to a world panel of 75 countries for five-year periods covering 1970-2000. Selective results are summarized in Table 10, which identifies the individual effects of four types of shocks, as well as their combined effect, on growth volatility. Controlling for significant domestic factors that raise growth volatility (inflation volatility, exchange-rate overvaluation, and systemic banking crises), the results reflect three consistent findings across most types of shocks. First, trade openness raises growth volatility while financial openness lowers growth volatility. Second, the volatility of most of the four types of foreign shocks raises growth volatility. Third, the significant interaction effects between openness and foreign shocks show that trade openness exacerbates the positive effects of foreign shocks on growth volatility while financial openness dampens the positive effects of foreign shocks on growth volatility.

Complementary results are reported by Calderón and Schmidt-Hebbel (2008f) based on similar data for 82 countries, covering 1975-2005, and using similar estimation techniques. Selective baseline results are summarized in Table 11. Among domestic conditions, fiscal and monetary policy volatility appear now as significant positive contributors to growth volatility. Trade openness does not affect growth volatility while financial openness dampens significantly growth volatility. Among external conditions, terms-of-trade volatility does not affect growth volatility but international real interest rate volatility raises significantly growth volatility.

What drives inflation in the world? In Calderón and Schmidt-Hebbel (2010) we address this question by identifying the empirical role of non-monetary inflation determinants in a world panel sample for 97 countries spanning 19752005. We extend the previous literature by specifying a broad inflation model that encompasses partial models found previously, applying several estimation techniques and testing for different linear and non-linear model specifications. Table 12 reports selective baseline results. The findings show that, controlling for high and hyper-inflation episodes and external inflation, either an IT regime or a fixed ER regime contribute to lower inflation. In countries under either regime, annual inflation declines by $3-5 \%$ in comparison to inflation in other countries. The result that IT reduces average inflation is due to the fact that the control group is comprised by all non-IT countries. If the control group were comprised only by low-inflation industrial countries, this result would vanish, as shown by Mishkin and Schmidt-Hebbel (2007). The fiscal theory of inflation is validated by the significant contribution of fiscal deficits to inflation. More financial openness contributes to lower inflation. 


\section{TABLE 9}

\section{GROWTH}

Dependent variable is growth rate of real GDP per capita

Estimation method: GMM-IV System Estimator

Sample: 77 Countries, 1970-2004

\begin{tabular}{|c|c|}
\hline Aid/GDP & $\begin{array}{c}0.2738 * * * \\
(0.031)\end{array}$ \\
\hline Aid/GDP squared & $\begin{array}{c}-0.0037 * * * \\
(0.001)\end{array}$ \\
\hline RER misalignment & $\begin{array}{c}-0.0164^{*} \\
(0.009)\end{array}$ \\
\hline Peace onset & $\begin{array}{c}-0.0030 \\
(0.004)\end{array}$ \\
\hline Postconflict period 1 & $\begin{array}{c}0.0378 * * * \\
(0.006)\end{array}$ \\
\hline Postconflict period 2 & $\begin{array}{c}-0.0273 * * * \\
(0.008)\end{array}$ \\
\hline Financial development (in logs) & $\begin{array}{c}0.0064 * * * \\
(0.002)\end{array}$ \\
\hline \multicolumn{2}{|l|}{ Interactions } \\
\hline RER misalignment $*$ aid/GDP & $\begin{array}{c}-0.3139 * * * \\
(0.114)\end{array}$ \\
\hline RER misalignment * financial development & $\begin{array}{c}0.0054^{*} \\
(0.003)\end{array}$ \\
\hline \multicolumn{2}{|l|}{ Standard Control Variables } \\
\hline Initial GDP per capita (in logs) & $\begin{array}{c}-0.0073 * * * \\
(0.002)\end{array}$ \\
\hline Initial GDP per capita (cyclical component) & $\begin{array}{c}-0.1836^{* * * *} \\
(0.014)\end{array}$ \\
\hline Inflation (in logs) & $\begin{array}{c}-0.0184 * * * \\
(0.002)\end{array}$ \\
\hline Government expenditures/GDP (in logs) & $\begin{array}{c}-0.0350 * * * \\
(0.004)\end{array}$ \\
\hline Human capital investment (in logs) & $\begin{array}{c}0.0217 * * * \\
(0.004)\end{array}$ \\
\hline Rule of law & $\begin{array}{c}0.0184 * * * \\
(0.002)\end{array}$ \\
\hline Observations & 367 \\
\hline Countries & 77 \\
\hline \multicolumn{2}{|l|}{ Specification tests (p-values) } \\
\hline Sargan test & 0.38 \\
\hline Second-order serial correlation & 0.29 \\
\hline
\end{tabular}

Note: * Significant at $10 \% ; * *$ significant at $5 \%$; ** significant at $1 \%$. 
TABLE 10

GROWTH VOLATILITY I

Dependent Variable: Standard Deviation of Growth in Real GDP per capita

Estimation Method: GMM-IV System Estimator

Sample: 75 Countries, 1970-2000

\begin{tabular}{|c|c|c|c|c|c|}
\hline & $\begin{array}{l}\text { Terms of } \\
\text { Trade } \\
\text { Changes }\end{array}$ & $\begin{array}{l}\text { Foreign } \\
\text { Growth }\end{array}$ & $\begin{array}{l}\text { World } \\
\text { Interest } \\
\text { Rate } \\
\text { Changes }\end{array}$ & $\begin{array}{l}\text { Regional } \\
\text { Capital } \\
\text { Inflows }\end{array}$ & $\begin{array}{c}\text { External } \\
\text { Shocks } \\
\text { (aggregate) }\end{array}$ \\
\hline \multicolumn{6}{|l|}{ Control Variables } \\
\hline $\begin{array}{l}\text { Inflation Volatility } \\
\text { (S.D. annual log differences of CPI) }\end{array}$ & $\begin{array}{c}0.169^{* *} \\
(0.02)\end{array}$ & $\begin{array}{c}0.169 * * \\
(0.04)\end{array}$ & $\begin{array}{c}0.123 * * \\
(0.03)\end{array}$ & $\begin{array}{c}0.114 * * \\
(0.03)\end{array}$ & $\begin{array}{c}0.084 * * \\
(0.02)\end{array}$ \\
\hline $\begin{array}{l}\text { RER Overvaluation } \\
\text { (Proportional index, overvaluation if }>100)\end{array}$ & $\begin{array}{c}0.001 * * \\
(0.00)\end{array}$ & $\begin{array}{c}0.001 * * \\
(0.00)\end{array}$ & $\begin{array}{c}0.002 * * \\
(0.00)\end{array}$ & $\begin{array}{c}0.001 * * \\
(0.00)\end{array}$ & $\begin{array}{c}0.002 * * \\
(0.00)\end{array}$ \\
\hline $\begin{array}{l}\text { Systemic Banking Crises } \\
\text { (Frequency of years under crises: } 0-1 \text { ) }\end{array}$ & $\begin{array}{c}0.200 * * \\
(0.04)\end{array}$ & $\begin{array}{c}0.254 * * \\
(0.06)\end{array}$ & $\begin{array}{c}0.240 * * \\
(0.04)\end{array}$ & $\begin{array}{c}0.214 * * \\
(0.05)\end{array}$ & $\begin{array}{c}0.280 * * \\
(0.05)\end{array}$ \\
\hline \multicolumn{6}{|l|}{ Openness: } \\
\hline $\begin{array}{l}\text { Trade Openness (TO) } \\
\text { (Real Exports and Imports to GDP, in logs) }\end{array}$ & $\begin{array}{c}-0.103 \\
(0.16)\end{array}$ & $\begin{array}{c}0.242 * * \\
(0.05)\end{array}$ & $\begin{array}{c}0.140 * * \\
(0.04)\end{array}$ & $\begin{array}{c}0.172 * * \\
(0.03)\end{array}$ & $\begin{array}{c}-0.056 \\
(0.08)\end{array}$ \\
\hline $\begin{array}{l}\text { Financial Openness (FO) } \\
\text { (Stock Equity-related Foreign liabilities to GDP, logs) }\end{array}$ & $\begin{array}{c}-0.015 * \\
(0.01)\end{array}$ & $\begin{array}{c}-0.036 * * \\
(0.01)\end{array}$ & $\begin{array}{c}-0.041 * * \\
(0.01)\end{array}$ & $\begin{array}{c}-0.043 * * \\
(0.00)\end{array}$ & $\begin{array}{c}-0.005 \\
(0.01)\end{array}$ \\
\hline \multicolumn{6}{|l|}{ Volatility of Foreign Shocks } \\
\hline $\begin{array}{l}\text { Volatility of Foreign Shocks (aggregate) 1/ } \\
\text { (weighted volatility of trade/financial shocks) }\end{array}$ & $\cdots$ & $\ldots$ & $\ldots$ & $\cdots$ & $\begin{array}{c}-0.584 * \\
(0.34)\end{array}$ \\
\hline $\begin{array}{l}\text { Volatility of Terms of Trade Changes } \\
\text { (S.D. annual log differences of ToT) }\end{array}$ & $\begin{array}{c}-0.633 * * \\
(0.25)\end{array}$ & $\begin{array}{c}0.127 * * \\
(0.02)\end{array}$ & $\begin{array}{c}0.130 * * \\
(0.02)\end{array}$ & $\begin{array}{c}0.129 * * \\
(0.02)\end{array}$ & $\ldots$ \\
\hline $\begin{array}{l}\text { Volatility of Foreign Growth Volatility } \\
\text { (S.D. annual log differences of Foreign Growth) }\end{array}$ & $\begin{array}{c}0.429 * * \\
(0.05)\end{array}$ & $\begin{array}{l}0.015 \\
(0.26)\end{array}$ & $\begin{array}{c}0.417 * * \\
(0.04)\end{array}$ & $\begin{array}{c}0.398 * * \\
(0.05)\end{array}$ & $\ldots$ \\
\hline $\begin{array}{l}\text { Volatility of World Real Interest Rate } \\
\text { (S.D. annual log differences of G-7 Interest Rates) }\end{array}$ & $\begin{array}{c}0.297 * * \\
(0.07)\end{array}$ & $\begin{array}{c}0.282 * * \\
(0.08)\end{array}$ & $\begin{array}{c}-0.646 * * \\
(0.26)\end{array}$ & $\begin{array}{c}0.276 * * \\
(0.07)\end{array}$ & $\ldots$ \\
\hline $\begin{array}{l}\text { Volatility of Regional Capital Inflows } \\
\text { (S.D. ratio of Regional Capital Flows to GDP) }\end{array}$ & $\begin{array}{c}0.200 * * \\
(0.03)\end{array}$ & $\begin{array}{l}0.203 * * \\
(0.04)\end{array}$ & $\begin{array}{c}0.207 * * \\
(0.03)\end{array}$ & $\begin{array}{c}0.706 * * \\
(0.22)\end{array}$ & $\cdots$ \\
\hline \multicolumn{6}{|l|}{ Interaction: Openness and Volatility of Foreign Shock } \\
\hline TO $*$ Volatility (Foreign Shock) & $\begin{array}{c}0.184 * * \\
(0.06)\end{array}$ & $\begin{array}{c}0.118 * * \\
(0.06)\end{array}$ & $\begin{array}{c}0.219 * * \\
(0.07)\end{array}$ & $\begin{array}{c}-0.122 * * \\
(0.06)\end{array}$ & $\begin{array}{c}0.421 * * \\
(0.08)\end{array}$ \\
\hline FO * Volatility (Foreign Shock) & $\begin{array}{c}-0.008 * * \\
(0.00)\end{array}$ & $\begin{array}{c}-0.010 * * \\
(0.00)\end{array}$ & $\begin{array}{c}0.019 * * \\
(0.01)\end{array}$ & $\begin{array}{c}-0.026 * * \\
(0.01)\end{array}$ & $\begin{array}{c}-0.026 * * \\
(0.00)\end{array}$ \\
\hline Observations & 364 & 364 & 364 & 364 & 364 \\
\hline Countries & 75 & 75 & 75 & 75 & 75 \\
\hline $\begin{array}{l}\text { Specification Tests (p-values) } \\
- \text { Sargan Test } \\
- \text { 2nd. Order Correlation }\end{array}$ & $\begin{array}{l}(0.48) \\
(0.26)\end{array}$ & $\begin{array}{l}(0.33) \\
(0.27)\end{array}$ & $\begin{array}{l}(0.34) \\
(0.22)\end{array}$ & $\begin{array}{l}(0.35) \\
(0.34)\end{array}$ & $\begin{array}{l}(0.25) \\
(0.24)\end{array}$ \\
\hline
\end{tabular}

Note: Numbers in parenthesis are robust standard errors. Regressions include constant and time dummies.

1 Our measure of the aggregate volatility of external shocks is calculated using the regression coefficients of the volatility of terms of trade shocks, foreign growth, world real interest rate fluctuations, and capital inflows to the region (as percentage of GDP).

* Significant at $10 \%$;* significant at $5 \%$; *** significant at $1 \%$. 


\section{TABLE 11}

GROWTH VOLATILITY II

Dependent Variable: Standard deviation of the growth rate of real GDP per capita (in logs) Methodology: Country and time-specific Fixed-Effects

Sample: 82 countries, 1975-2005

Trade Openness (TO)

Trade: Real exports and imports

$\begin{array}{ll}-0.025 & -0.019\end{array}$

(as \% of GDP, in logs)

(0.13)

$(0.14)$

Financial Openness (FO)

Foreign Liabilities

$-0.169 * *$

(as \% of GDP, in logs)

(0.07)

Foreign Assets and Liabilities

(as \% of GDP, in logs)

\section{Domestic Conditions}

Income per capita

0.155

0.184

(in logs)

$(0.14)$

$(0.14)$

Inflation

0.044

0.042

(CPI inflation rate, in logs)

$(0.11)$

$(0.11)$

REER overvaluation index

$0.150 * *$

$0.151 * *$

(in logs)

$(0.07)$

$(0.07)$

Systemic Banking Crisis

0.073

0.071

(average frequency of systemic banking

(0.10)

(0.10)

crises)

Fiscal Policy Volatility 1/

$0.217 * *$

$0.215 * *$

(0.05)

$(0.05)$

Monetary Policy Volatility 1/

$0.196 * *$

$0.195 * *$

(0.05)

(0.05)

External Conditions

Terms of Trade Volatility

0.026

0.025

(std. dev. of terms of trade shocks, in logs)

(0.02)

$(0.02)$

International Real Interest Rate Volatility

(std. dev. of the prime loan rate, in logs)

$0.173 * *$

$0.163 * *$

(0.08)

(0.08)

Observations

474

474

Adjusted $\mathrm{R}^{2}$

0.193

0.193

Note: The numbers in parenthesis below the coefficient estimates are the robust standard errors.

1 Monetary and Fiscal Policy Volatility are calculated using the methodology of Fatas and Mihov (2003, 2006). For fiscal policy volatility we regress government spending (as a ratio to GDP) on output, growth and lagged government spending, and we instrument output growth with lagged output growth and current and lagged values of oil prices. The same methodology is applied to monetary policy using the ratio of money supply to GDP.

* Significant at 10\%; ** significant at 5\%; *** significant at $1 \%$. 
TABLE 12

INFLATION

Dependend Variable: Normalized Inflation

Estimation: Fixed-Effects-IV

Sample: 65 Countries, 1975-2005

\begin{tabular}{|c|c|c|}
\hline & Fixed Effects IV & Random Effects IV \\
\hline \multicolumn{3}{|l|}{ Inflation Related Variables } \\
\hline Lagged Inflation & $\begin{array}{c}0.160 * * * \\
(1.97)\end{array}$ & $\begin{array}{c}-0.033 \\
(0.22)\end{array}$ \\
\hline Hyper Inflation & $\begin{array}{c}0.348 * * * \\
(9.29)\end{array}$ & $\begin{array}{c}0.488 * * * \\
(6.54)\end{array}$ \\
\hline High Inflation & $\begin{array}{c}0.232 * * * \\
(14.02)\end{array}$ & $\begin{array}{c}0.308 * * * \\
(8.29)\end{array}$ \\
\hline \multicolumn{3}{|l|}{ Monetary and Exchange-Rate Regime } \\
\hline Inflation Targeting & $\begin{array}{c}-0.051 * * * \\
(5.41)\end{array}$ & $\begin{array}{c}-0.045 * * * \\
\quad(4.25)\end{array}$ \\
\hline Exchange Rate Targeting & $\begin{array}{c}-0.029 * * * \\
(7.70)\end{array}$ & $\begin{array}{c}-0.037 \text { *** } \\
(5.97)\end{array}$ \\
\hline \multicolumn{3}{|l|}{ Openness } \\
\hline Trade Openness & $\begin{array}{c}-0.009 \\
(0.81)\end{array}$ & $\begin{array}{c}-0.012 * * \\
(2.15)\end{array}$ \\
\hline Financial Openness & $\begin{array}{c}-0.013 * * * \\
(5.94)\end{array}$ & $\begin{array}{c}-0.011 * * * \\
(4.90)\end{array}$ \\
\hline Relevant External Inflation & $\begin{array}{c}0.210 * * * \\
(3.11)\end{array}$ & $\begin{array}{c}0.412 * * * \\
(4.77)\end{array}$ \\
\hline \multicolumn{3}{|l|}{ Structural / Institutional Variables } \\
\hline Fiscal Surplus & $\begin{array}{c}-0.204 * * * \\
(5.30)\end{array}$ & $\begin{array}{c}-0.179 * * * \\
(4.46)\end{array}$ \\
\hline Income per Capita & $\begin{array}{c}-0.040 * * * \\
(3.67)\end{array}$ & $\begin{array}{c}0.012 * * * \\
(3.09)\end{array}$ \\
\hline Domestic Private Credit & $\begin{array}{c}0.018 * \\
(1.87)\end{array}$ & $\begin{array}{c}-0.059 * * * \\
(4.65)\end{array}$ \\
\hline Democratic Accountability & $\begin{array}{c}-0.002 \\
(1.22)\end{array}$ & $\begin{array}{c}-0.003 * \\
(1.65)\end{array}$ \\
\hline \multicolumn{3}{|l|}{ Cyclical Domestic and Foreign Variales } \\
\hline Cyclical component of Oil Prices & $\begin{array}{c}0.019 * * \\
(2.01)\end{array}$ & $\begin{array}{l}0.017 \\
(1.48)\end{array}$ \\
\hline National Output Gap & $\begin{array}{c}0.238 * * * \\
(3.60)\end{array}$ & $\begin{array}{l}0.057 \\
(0.55)\end{array}$ \\
\hline Foreign Output Gap (weighted by GDP) & $\begin{array}{c}-0.204 \\
(0.93)\end{array}$ & $\begin{array}{c}-0.406 \\
(1.40)\end{array}$ \\
\hline Constant & $\begin{array}{c}0.467 * * * \\
(4.80)\end{array}$ & $\begin{array}{c}0.086 * * * \\
(3.68)\end{array}$ \\
\hline Observations & 1574 & 1574 \\
\hline Countries & 65 & 65 \\
\hline Hausman test (RE vs FE) p-value & & 0.00 \\
\hline $\mathrm{R}^{2}$ & 0.75 & 0.79 \\
\hline
\end{tabular}

Note: Absolute value of $\mathrm{t}$ statistics in parentheses. * significant at $10 \%$; ** significant at $5 \%$; *** significant at 1 . 


\section{Conclusions}

I have summarized in this paper the findings of a large research project conducted with several co-authors over the last years. This research agenda has focused on the empirical determinants of (and interrelations between) macroeconomic regimes, policies, and performance in the world. Motivated by a large previous literature that often yields scattered, ambiguous and even contradictory results, this research project has developed a more systematic empirical search of the determinants of macroeconomic regimes, policies, and outcomes in the world at large.

The project's hypotheses are structured into three related themes: the likelihood of adoption of macroeconomic policy regimes, the success of macroeconomic policies, and the performance of two key macroeconomic variables. A large world database was assembled for this project from both publicly available and private databases. Data coverage extends to more than 100 countries, with annual time series extending, at most, from 1970 to 2008. A wide spectrum of frontier estimation techniques was applied to the country panel data series, appropriate for discrete-choice and continuous variable estimation. The key research results are the following.

Country choice of macroeconomic policy regimes (exchange-rate regimes, money growth targeting, inflation targeting, and rule-based fiscal regimes) is explained by countries' structural and institutional features, good macroeconomic performance, financial development, and international integration. The cyclical behavior of fiscal policy reflects the quality of country institutions, financial openness, and financial development. Central bank accuracy in meeting inflation targets is also a result of domestic institutional strength and macroeconomic credibility. Long-term growth is significantly shaped by the quality of policies, financial development, foreign aid, and exchange-rate misalignment, in addition to standard growth determinants. Growth volatility is a result of domestic policy volatility, external shocks, international integration, and financial development. Country inflation rates are determined by international factors and domestic determinants, including fiscal policy, institutional development, monetary and exchange-rate regimes, and financial depth and openness.

\section{REFERENCES}

Albagli, E. and K. Schmidt-Hebbel. (2008). "By How Much and Why do Inflation Targeters Miss Their Targets?", Central Bank of Chile, manuscript, March.

Alesina, A., F. Campante and G. Tabellini. (2008). "Why is fiscal policy often procyclical?", Journal of the European Economic Association 6 (5): 1006-1036.

Arellano, M. and S. Bond. (1991). "Some Tests of Specification for Panel Data: Monte Carlo Evidence and an Application to Employment Equations". Review of Economic Studies 58 (2), 277-97.

Arellano, M. and O. Bover. (1995). "Another Look at the Instrumental Variable Estimation of Error-Component Models". Journal of Econometrics 68 (1), 29-51. 
Batini, N. and D. Laxton. (2007). "Under what Conditions can Inflation Targeting be adopted? The Experience of Emerging-Market Economies". In F. Mishkin and K. Schmidt-Hebbel (eds.) Monetary Policy under Inflation Targeting. Santiago: Central Bank of Chile.

Bernanke, B.S. (2010). Fiscal sustainability and fiscal rules, speech at the Annual Meeting of the Rhode Island Public Expenditure Council, Providence, Rhode Island, 4 October.

Bernanke, B.S., T. Laubach, F. Mishkin and A. Posen. (1999). Inflation Targeting: Lessons from the International Experience. Princeton University Press.

Blundell, R. and S. Bond. (1998). "Initial Conditions and Moment Restrictions in Dynamic Panel Data Models". Journal of Econometrics 87 (1), 11543.

Beker, E. (2006). "Exchange Rate Regime Choice”. Panoeconomicus 3, 313334.

Caballero, R. and A. Krishnamurthy. (2004). Fiscal Policy and Financial Depth. NBER Working Paper 10532, May.

Calderón, C., R. Duncan and K. Schmidt-Hebbel. (2004). “The Role of Credibility on the Cyclical Properties of Macroeconomic Policies in Emerging Economies", Review of World Economics, 140 (4): 613-33.

Calderón, C., R. Duncan and K. Schmidt-Hebbel. (2010). "Institutions and Cyclical Properties of Macroeconomic Policies in the Global Economy", Catholic University of Chile, manuscript, April.

Calderón, C., N. Loayza and K. Schmidt-Hebbel. (2006). "External Conditions and Growth Performance", in R.J. Caballero, C. Calderón, and L.F. Céspedes (editors): External Vulnerability and Preventive Policies. Central Bank of Chile, Santiago.

Calderón, C., N. Loayza and K. Schmidt-Hebbel. (2008). "Does Openness Imply Greater Vulnerability?", Central Bank of Chile Working Paper $\mathrm{N}^{\circ} 485$, September.

Calderón, C. and K. Schmidt-Hebbel. (2003). "Macroeconomic Policies and Performance in Latin America", Journal of International Money and Finance, 22 (7): 895-923.

Calderón, C. and K. Schmidt-Hebbel. (2008a). "Choosing an Exchange Rate Regime", Central Bank of Chile Working Paper No 494, October.

Calderón, C. and K. Schmidt-Hebbel. (2008b). "What drives the Choice of Money-based Targets in the World", Central Bank of Chile Working Paper $\mathrm{N}^{\circ}$ 479, August.

Calderón, C. and K. Schmidt-Hebbel. (2008c). "What drives the Choice of Inflation Targets in the World", Central Bank of Chile, manuscript, March.

Calderón, C. and K. Schmidt-Hebbel. (2008d). "The Choice of Fiscal Regimes in the World", Central Bank of Chile Working Paper No 487, September.

Calderón, C. and K. Schmidt-Hebbel. (2008e). "Business Cycles and Fiscal Policies: The Role of Institutions and Financial Markets", Central Bank of Chile Working Paper $\mathrm{N}^{\circ}$ 481, August.

Calderón, C. and K. Schmidt-Hebbel. (2008f). "Openness and Growth Volatility", Central Bank of Chile Working Paper $\mathrm{N}^{\circ} 483$, September.

Calderón, C. and K. Schmidt-Hebbel. (2010). "What Drives Inflation in the World?", in R. Fry, C. Jones, and C. Kent: Inflation in an Era of 
Relative Price Shocks, Reserve Bank of Australia and Centre for Applied Macroeconomic Analysis of The Australia National University.

Carare, A. and M. Stone. (2003). "Inflation Targeting Regimes". IMF Working Paper WP/03/9.

Edison, H.J. and M. Melvin. (1990). "The determinants and implications of the choice of an exchange rate regime". In: Haraf, W.S., and T.D. Willett (eds.) Monetary Policy for a Volatile Global Economy. Washington, DC: AEI Press.

Elbadawi, I., L. Kaltani and K. Schmidt-Hebbel. (2008). "Foreign Aid, the Real Exchange Rate, and Economic Growth in the Aftermath of Civil Wars", The World Bank Economic Review, 22 (1): 113-140.

Gavin, M. and R. Hausmann. (1998). "Macroeconomic Volatility and Economic Development", Proceedings of the IEA, Conference Volume $\mathrm{N}^{\mathrm{o}} 119$ : 97-116.

Gavin, M., R. Hausmann, R. Perotti, R. and E. Talvi. (1996). "Managing Fiscal Policy in Latin America and the Caribbean: Volatility, Procyclicality, and Limited Creditworthiness". Inter-American Development Bank, Office and the Chief Economist, Working Paper 326, March

Gavin, M. and R. Perotti. (1997). "Fiscal Policy in Latin America". In: NBER Macroeconomics Annual. Cambridge and London: MIT Press, 11-61.

Gerlach, S. (1999). "Who targets Inflation explicitly?" European Economic Review, 43, 1257-1277.

Hausmann, R. and E. Stein. (1996). "Searching for the Right Budgetary Institutions for a Volatile Region", Inter-American Development Bank Working Paper 315.

$\mathrm{Hu}, \mathrm{Y}$. (2006). "The choice of inflation targeting - an empirical investigation". International Economics and Economic Policy 3 (1), 27-42.

Juhn, G. and P. Mauro. (2002). "Long-run determinants of exchange rate regimes: A simple sensitivity analysis”. IMF Working Paper WP/02/104, June.

Kaminsky, G., C. Reinhart and C. Végh. (2004). "When It Rains, It Pours: Procyclical Capital Flows and Macroeconomic Policies". In NBER Macroeconomics Annual, edited by M. Gertler and K. Rogoff, Cambridge, MA, MIT Press.

Kydland, F. y E. Prescott. (1977). "Rules rather than Discretion: The Inconsistency of Optimal Plans", Journal of Political Economy 85 (3): 473-491.

Lane, P.R. (2003a). "Business Cycles and Macroeconomic Policies in Emerging Market Economies", International Finance 6(1): 89-108.

Lane, P.R. (2003b). "The Cyclical Behaviour of Fiscal Policy: Evidence from the OECD”, Journal of Public Economics 87 (12): 2661-2675.

Levy-Yeyati, E., F. Sturzenegger and I. Reggio. (2006). "On the endogeneity of exchange rate regimes". John F. Kennedy School of Government Faculty Research Working Paper Series RWP06-047, November.

Lucas, R. (1976). "Econometric Policy Evaluation: A Critique", in K. Brunner and A, Meltzer (eds.): The Phillips Curve and Labor Markets, CarnegieRochester Conference Series on Public Policy, 1: 19-46,

Masson, P., M. Savastano and S. Sharma. (1997). "The Scope for Inflation Targeting in Developing Countries". IMF Working Paper No 97/130.

Mishkin, F. and K. Schmidt-Hebbel. (2002). "A Decade of Inflation Targeting in the World: What do we know and what do we need to know? In Inflation 
Targeting: Design, Performance, Challenges, edited by Norman Loayza and Raimundo Soto. Santiago: Central Bank of Chile.

Mishkin, F. and K. Schmidt-Hebbel. (2007). "Does Inflation Targeting Make a Difference?" In F. Mishkin and K. Schmidt-Hebbel (eds.) Monetary Policy under Inflation Targeting. Santiago: Central Bank of Chile.

Pesaran, H.M., Y. Shin and R.P. Smith. (1999). "Pooled Mean Group Estimation of Dynamic Heterogeneous Panels". Journal of the American Statistical Association 94: 621-634.

Riascos, A. and C.A. Végh. (2004). "Procyclical Fiscal Policy in Developing Countries: The Role of Cpital Market Imperfections". University of California at Los Angeles, manuscript, May.

Schmidt-Hebbel, K. (2010). "Inflation Targeting Twenty Years on: Where, When, Why, With what Effects, What lies ahead?", Catholic University of Chile, manuscript.

Stein, E., E. Talvi and A. Grisanti. (1998). "Institutional Arrangements and Fiscal Performance: The Latin America Experience", NBER Working Paper 6358.

Talvi, E. and C. Végh. (2005). "Tax Base Variability and Procyclical Fiscal Policy". Journal of Development Economics 78: 156-90. 
